\title{
Women and Tenure Transition: An Examination of Land Access and Gendered Land Rights in Kanungu District, Uganda
}

Emmalee McDonald

Portland State University

Follow this and additional works at: https://pdxscholar.library.pdx.edu/mcnair Let us know how access to this document benefits you.

\section{Recommended Citation}

McDonald, Emmalee (2011) "Women and Tenure Transition: An Examination of Land Access and Gendered Land Rights in Kanungu District, Uganda," PSU McNair Scholars Online Journal: Vol. 5: Iss. 1, Article 19.

https://doi.org/10.15760/mcnair.2011.145 
Portland State University McNair Research Journal 2011

Women and Tenure Transition: An Examination of Land Access and Gendered Land Rights in Kanungu District, Uganda

\author{
by \\ Emmalee McDonald
}

Faculty Mentor:

Ellen Bassett

Citation: McDonald, Emmalee. Women and Tenure Transition: An Examination of Land Access and Gendered Land Rights in Kanungu District, Uganda. Portland State University McNair Scholars Online Journal, Vol. 5, 2011: pages [155-197] 
Women and Tenure Transition:

An Examination of Land Access and Gendered Land Rights in Kanungu District, Uganda

\author{
Emmalee McDonald \\ Faculty Mentor: Ellen Bassett, PhD \\ McNair Scholars Program \\ Portland State University
}

\begin{abstract}
Access to land and land rights are critical to development and poverty reduction. Currently Uganda, like many countries around the globe, is undergoing transformation of its land tenure systems, away from traditional, community-based institutions towards private individual freehold property. Privatizing land rights, however, is controversial; critics fear that this will negatively impact vulnerable groups, such as women. In the Ugandan context while new privatization reforms have passed, they have not been fully implemented. This tenure transition is creating confusion and reportedly leading to a weakening of the traditional systems and an erosion of women's land rights. I examine women's land rights in rural southwestern Uganda, with a specific focus on women's ability to access land subsequent to the 1998 Land Act. In my work I ask: how do women perceive their land rights? What strategies have women developed to facilitate their access to land? Do women believe the 1998 Land Act inhibited or aided in their struggle for land? The research utilized three data collection methods: document analysis, informant interviews with local elites, and semi-structured interviews with rural female farmers. Data analysis revealed three main themes: women lack awareness of the new land laws, issues around security of tenure occurred due to the transitioning tenure system combined with gender inequality, and women are utilizing informal channels to access land tenure while focusing on development.
\end{abstract}





\section{Introduction}

In 1998 the Uganda Parliament passed a new Land Act that provided the legal framework for the transformation of customary land to freehold. This was a key part of the land reform agenda that has been a focus for the government since coming into power in 1986 (Adoko \& Levine, 2008). The movement towards freehold tenure and away from customary systems of land regulation and distribution had its foundation set during the colonial period, and has gained momentum through time by being represented as a poverty alleviation method. Uganda is one of many countries that have undergone such a transformation. The widespread transformation of land tenure has lead to a heated debate about whether the movement towards individualized tenure systems is beneficial or harmful for the diverse set of countries in which it is being applied. In addition, many theorists argue that this move towards private tenure systems diminishes women's rights, which they contend were well protected under the customary systems of land tenure.

Within the Ugandan context, the passing of the 1998 Land Act was controversial due to the movement away from the customary, as well as the inclusion, or lack there of, of women's rights. This controversy revolved around the Co- Ownership Amendment, which would have provided equal ownership for married couples for the land on which they resided. However, during the passing of the bill, this amendment was omitted. As a result, women have only one provision of the 1998 Land Act to rely upon, which is the Consent Clause that requires the consent of both spouses for the sale of land.

This legislative history represents an interesting contradiction in the Ugandan setting. Most notably, the Ugandan Government acknowledged and took action to empower women so that they could take dynamic roles in society. The most important step was to intentionally include women in political positions. In the 1995 Constitution, gender equality was highlighted through allocating one third of the local council government member positions for women (Ahikire, 2007). Gender equality has also been acknowledged to be a key factor in alleviating 
poverty, as described in The National Action Plan On Women (Ministry of Gender, Labor and Social Development, 2007), yet there is still strong hesitation in taking action to protect women's land access. As customary systems of tenure are weakened due to the passing of the Land Act, women's rights are left to slip through the cracks of the overlapping and transitioning land tenure system in Uganda. Thus, a decade after the Land Act was passed one can ask: what has been the implication of the Act for women in terms of access to land? Specifically in rural settings (where information is not as readily accessible and land ever more important) how are women navigating the overlapping systems of customary and freehold tenure? What sort of awareness is there of the Land Act; and what preferences do women have concerning the best means of accessing land?

This paper examines these questions, first by exploring the theoretical debate between customary and freehold, then going into a brief history of land tenure in Uganda including a section specifically on women's inclusion in politics and the 1998 Land Act. After an explanation of the methodology the paper is rounded out by presenting the findings from field research and is wrapped up with a brief discussion and a look at the potential next steps.

\section{From Customary Towards Freehold}

Uganda is not alone in its process of land tenure transformation from customary to freehold. This has also occurred in Uganda, Kenya, Tanzania, and Rwanda, (Englert and Daley, 2008) as well as many other countries across Africa. These programs have been promoted and made possible through funding from bi and multi-lateral aid organizations such as USAid, the World Bank and the Department for International Development (DfiD) (Manji, 2006). These land reforms have been pitched as a method to address issues of inequality, and poverty, as well as a means for investment, sustainability and innovation in agriculture.

Empirical studies show that results have been mixed, much inefficiency has arisen, and the guarantees that were supposed to come with a freehold tenure system have yet to come to fruition (Manji, 2006). With the lack of positive results many analysts have criticized the push 
towards a freehold system (Manji, 2006, Lastarria-Cornhiel 1997). This school of thought acknowledges the merit in customary tenure systems and argues that not only are freehold tenure systems not working, but they also can have detrimental effects. Thus the debate is between those who believe in protecting and enhancing the communal and traditional rights, and those who see the need to take part in the global free market system by creating private property systems through land titling. As Catherine Boone (2007, p.557) states, this debate is "pitting those who advocate growth-promoting individualization and transferability of property rights against those who want to use land tenure policy to protect the use rights and subsistence rights of farmers”.

The push towards freehold tenure has been popularized by the work of Hernando De Soto (2000), a Peruvian economist in his book The Mystery of Capital: Why Capitalism triumphs in the West and Fails Everywhere Else. He argues that to increase productivity and growth in the developing world, the poor living in the global south need capital, and the road to capital must be paved with legal titling. Titling, he argues, would free up “dead capital”, meaning that with a title individuals and families excluded by informal status can turn their home into an asset and thus be able to access loans, and have a chance to enter into the global market. . De Soto (2000) states, “They hold these resources in defective forms: houses built on land whose ownership rights are not adequately recorded.... because the rights to these possessions are not adequately documented, these assets of narrow local circles where people know and trust each other, cannot be used as collateral for a loan, and cannot be used as a share against an investment” (p.6). He argues that it is capital that has made the West wealthy and it is the lack thereof that has left the other five sixths of humanity behind (De Soto, 2000). Poverty thus, is caused not by a lack of assets in poor communities, but a lack of legal registration for those assets and the benefits that come with them (Sjaasdtad \& Cousins 2008).

While the argument is persuasive, during the last two decades in which De Soto’s ideas have prevailed and effected land law reform throughout Africa and the developing world, evidence has accrued that has strongly contradicted his theory. It has been found that not only is 
there a lack of ability to implement and uphold titling systems, but that there are also many negative effects that can and do occur when titling is implemented (Sjaasdtad, 2008). Due to this reality there have been a number of critiques of De Soto's including that he: oversimplifies the solution to poverty, assumes that there is a desire for and an ability to access credit markets, assumes that governments have the ability to implement and uphold a legal paper land title system once it is passed, and fails to consider the exclusionary effects of the titling process on women's access to land and thus is not acknowledging the vital role that women must play in poverty alleviation.

A key critique of De Soto's work is that the emphasis on privatization does not take into consideration the local social structures within which these ideas are being implemented (Manji, Lastarria-Cornhiel, Nyamu-Musembi). Within the African context access to land is regulated primarily by social arrangements rather then the market system, land transactions are overseen by the local community usually by an elder or chief and the transference of land is not something that is taken lightly (Lastarria-Cornhiel, 1997). A legally recognized peace of paper (a title) doesn't hold as much weight as ones surrounding community, which provides one of the most necessary ingredients of property, recognition by others in society (Platteau, 1996). A common presumption of the West is that everyone views the freedom to dispose of land as they see fit as central to their land rights, but in the African context many have argued this is not the case. (Nyamu-Musembi, 2008) Focusing on the law as the means of regulating tenure, reduces land to an economic object alone, and thus misses the intricate social fabrics that are tied to land and the many different manners in which individuals view land. As Manji (2006:20) states,

"The multitudes of ways in which people relate to and perceive of land as well as their fellow landholders are denied by legal centralism. In deprecating informal land tenure arrangements as backward and economically inefficient, advocates of formalization suggest that it is only by bringing these arrangements into the formal legal system of the state that there value can be realized. This approach fails to acknowledge the multitude of ways in which people deal in land”. 
There is evidence that the social fabric is indeed being weakened in Uganda. As the customary system of land tenure is impacted by the increase of influence of the market system, sales become more common (Lastarria-Cornhiel, 1997). The increase in land sales has occurred due to a decrease in social ties as well as a change of understanding of land as an asset, rather than as a source of food, changing the value of land from its ability to provide sustenance to a commodity that has cash value (Lastarria-Cornhiel, 1997). This process of joining in the market system releases communities from the systems of protection and increases transferability, which in many cases has led to increased insecurity (Adoko \& Levine, 2008). A recent empirical study conducted in the Apac District of Uganda found an increased in sales of customary held land. Predominantly these sales were conducted without the knowledge of the female head of family and occur due to pressure from impoverished living conditions (Adoko \& Levine, 2008). Implementing a system that is rooted in market system ideologies as a means of alleviating poverty does not consider the well established understanding that the possibility for transferability can lead to the sale of land by the poor in times of economic hardship and insecurity (Fortin, 2005). These sales lead to loss of land for women and children and should in theory be stopped by customary law (Adoko \& Levine, 2008).

Implementation of new tenure systems has proved to be a struggle for many countries (Manji, 2001), due to cost, combined with the lack of social acceptance. Expenses come in the form of titling, surveying and registration. These processes are estimated to cost hundreds of dollars per property and billions for a nation (Sjaasdtad, 2008). Countries are facing the high cost of implementing a titling system while simultaneously struggling with the social challenges that come with attempting to gain acceptance of a new tenure model. In most African countries the implementation process occurred without clear definition of who was responsible or evaluation of the government’s competency (Deininger \& Castagnini, 2006). In Uganda many important land tenure regulating institution are either missing all together or barely functional due to lack of financial support (Adoko \& Levine, 2008). De Soto (2000) himself discusses the need for 
providing an easy pathway into the legal titling system for this transition to be successful. He reports that the only way to bring people into this new legal system of land tenure is if the "government makes it easy, safe, and cheap” (p.179). With the state’s inability to implement, the population must choose between a well-established local customary system and a state system that is deficient. When faced with these options, the community will choose the customary (Bromley, 2008).

Another critique of De Soto is his failure to acknowledge that the titling process may have negative distributional consequences. Certain groups may be better positioned to gain titling (e.g. urban elites); while others may be strongly disadvantaged. Within the African context women have been historically the losers as this transition to individualized freehold occurs (Englert and Daley, 2008).

To understand how this transpires it is important to understand how women predominantly access land. To do this we must make the distinction between access and control of land. Control of land is based on the idea of ownership; this establishes the command of that individual over the land and the benefits that are derived from the land. Access, on the other hand does not include ownership, but establishes the individual's ability to make use of the land (Lastarria-Cornhiel, 1997). African women predominantly have user rights that they have acquired from their husband through the customary system (Nyamu-Musembi, 2008). This occurs when a woman is married and moves from her home to the husband's land, the husband allocates a plot of the family land to the wife for cultivation of food for family consumption and through this process she is given the right to utilize that piece of land (Lastarria-Cornhiel, 1997). Within the allocation of user rights, women have limited say in the transference or dispossession of land (Adoko and Levine, 2008). This limitation in terms of power over land is exacerbated during the transition into a private property system (Lastarria-Cornhiel, 1997).

The creation of an individualized land ownership system puts at risk those with secondary or indirect rights to land such as women (Bikaako \& Ssenkumba, 2003). Titling and 
registration programs tend to award land to individual heads of household, granting the owner more exclusionary rights. "Thus one impact of land titling to individual persons is to significantly decrease a customary community’s ability to ensure the subsistence of all its members (i.e. women) through land access” (Lastarria-Cornhiel, 2003, p.6). This is due to the concentration of land rights in the hands of the head of household (generally a man). This combined with a lack of joint registration leads to a weakening of women's ability to access land (Nyamu-Musembi, 2008; Bikaako \& Ssenkumba, 2003).

Protecting women's land rights is necessary to address issues of poverty and inequality in Africa. Land is a pivotal issue due to the fact that it is the base of life in Uganda; as in all of Africa-people depend on it for their livelihoods as well as for subsistence. Women take a huge part in food production (Tripp, 2004); according to Bikaako and Ssenkumbas, (2003: 276) women account for 70-80 percent of the labor in agricultural production but only own about 7 percent of the land (Sebina-Zziwa, 1995, 6). The importance of this issue is apparent when looking at the direct connection between access to land and quality of life in an agrarian society. As women are the backbone of food production for their family, their ability to access land directly connects with their ability to provide food for their family unit (Tripp, 2004).

The issue of women's role in society as a means of alleviating poverty is being addressed on the global scale-many leaders and well known activists see it as the issue of our time. Hillary Clinton recently said:

I happen to believe that the transformation of women's roles is the last great impediment to universal progress - that we have made progress on many other aspects of human nature that used to be discriminatory bars to people's full participation. But in too many places and too many ways, the oppression of women stands as a stark reminder of how difficult it is to realize people's full human potential (Landler, 2009).

A: Brief History of Land Tenure in Uganda:

The history of land tenure in Uganda can be broken down into three main stages; pre colonialism, the colonial period and post-colonial period up to present day. The historical context 
casts light on the manner in which women's land rights have transformed, or been slowly diminished, through time. Within this section I will summarize the first two stages. Two sections will follow this, one that explores the current political setting in Uganda, and another that looks at the 1998 Land Act.

In Uganda there are many stories, legends, and much literature that would lead us to believe that women in many cases owned land on the same footing as men in pre colonial times (Sebina-Zziwa, 1995). Although there are mixed understandings of how land was managed and who had access to what resource, a common understanding is that land served the whole community and acted as a foundation for strong social ties. In Bikaako and Ssenkumbas (2003) chapter in the book Women and Land in Africa they discuss the history of land rights in Uganda. They point out that in most areas land was vested in the community with the elder/ruler as owner or trustee. As the head of the tribe or clan, the elder had the authority to allocate land, settle disputes, and over see the community. With this position came great influence but also responsibility to manage the land in the interest of the community. Historically distribution of land between genders was mixed, while in some areas it was men who inherited the land; there were also some tribes (such as the Toro) that practiced matrilineal inheritance (Bikaako \& Ssenkumbs 2003). Toro women could inherit property and could get the right of occupation of customary land from the chief (Bikaako \& Ssenkumbs 2003). While historically not all tribes practiced matrilineal inheritance, it is argued that women's rights to land were still well protected through user rights under the customary tenure system (Adoko \& Levine 2008; Bikaako \& Ssenkumbs 2003).

During the 1900's the British had a transformational influence on the land tenure system in the country, pulling it away from what they considered to be the "backward" communal tenure model towards the individual freehold system (Adokok \& Levine 2008). The colonialists introduced the idea of individual land holdings with the "mailo” tenure system. The mailo system was introduced in areas where the land was previously communally owned; chiefs were given 
large estates of land, which were held by them under "mailo" tenure with the previous customary holders of the land becoming tenants. These smallholding farmers still had the legal right to cultivate the land but soon this was accompanied with rent that needed to be paid to the chief (Bikaako \& Ssenkumba 2003). The initial Kingdoms grant of mailo rights included were the Buganda, Toro and Ankole, but by 1926 the groups involved included all of the Ugandan Protectorate, which encompassed 5 Kingdoms (Kingdoms: Ankole, Buganda, Toro, Busoga, Bunyoro) and 10 Districts (Districts: West Nile, Madi, Acholi, Karamoja, Lango, Teso, Sebei, Bugisu, Bukedi, Kigezi) (Batunig, 2008). The implementation of the "mailo” tenure system by the British was the beginning of a tenure method that resembled a freehold tenure system (Bikaako \& Ssenkumba 2003). Freehold means a tenure system in which the owner has full ownership rights under the law, thus concentrating all aspects of land access into the hands of the individual owner (Tripp, 2004). In Women and Land in Africa, Bikaako and Ssenkuma point out that during this time freehold tenure was still uncommon, it was held only by privileged groups, such as kings, chiefs and owners of large-scale agricultural developments. Although uncommon, the freehold system introduced the idea of transference rights, meaning that those with land under freehold had the right to lease, mortgage or sell their land. The authors discuss how these rights were introduced with the understanding that the transference of land was still beholden to the public good, but this understanding was diminished over time as legislation was implemented that focused the rights to land in the hands of the head of household. (Bikaako \& Ssenkumba 2003).

During the colonial period women's rights to land were weakened through this legislation that promoted the rights of the head of household, while also diminishing the importance of subsistence agriculture (Tripp 2004). The legislative reforms passed in this period include the 1962 Public Land Ordinance, the 1969 Public Land Act and the 1975 Land Reform Decree, in which the British colonialist government introduced new tenure models (beyond mailo), including both leasehold and freehold. In these colonial land laws, women's use rights were not valued, due to a lack of understanding that the value of land could be perceived in terms of use 
(Bikaako \& Ssenkumba, 2003). The colonial promotion of individual rights assigned to the head of household, reflected the colonial administration's desire to redefine land for Africans in the western tradition. This diminished the social and customary laws protecting women's land rights (Tripp 2004).

B: Post Colonialism, Women's Inclusion in Politics and the 1998 Land Act:

Currently Uganda has a decentralized form of government. This means that the central government transfers a portion of its power of financial, managerial and political decision making to local government, which in turn gives them the power to manage the local affairs in the context of a unitary state (Nsimambi, 1998). This is done through a five-tiered system of elected councils that connects every village to a district, and the districts to the central government (Ahikire 2007). In theory the smaller localized government provides an easily accessible avenue that draws in the local population and thus creates a government that has an active populace who are informed and involved in the workings of its leaders. Through this process of empowerment the hope is that community members will use their voice to take control of their political, social and economic destiny (Nsimbambi, 1998). 
Graphic 1: The Ugandan Local Council Structure

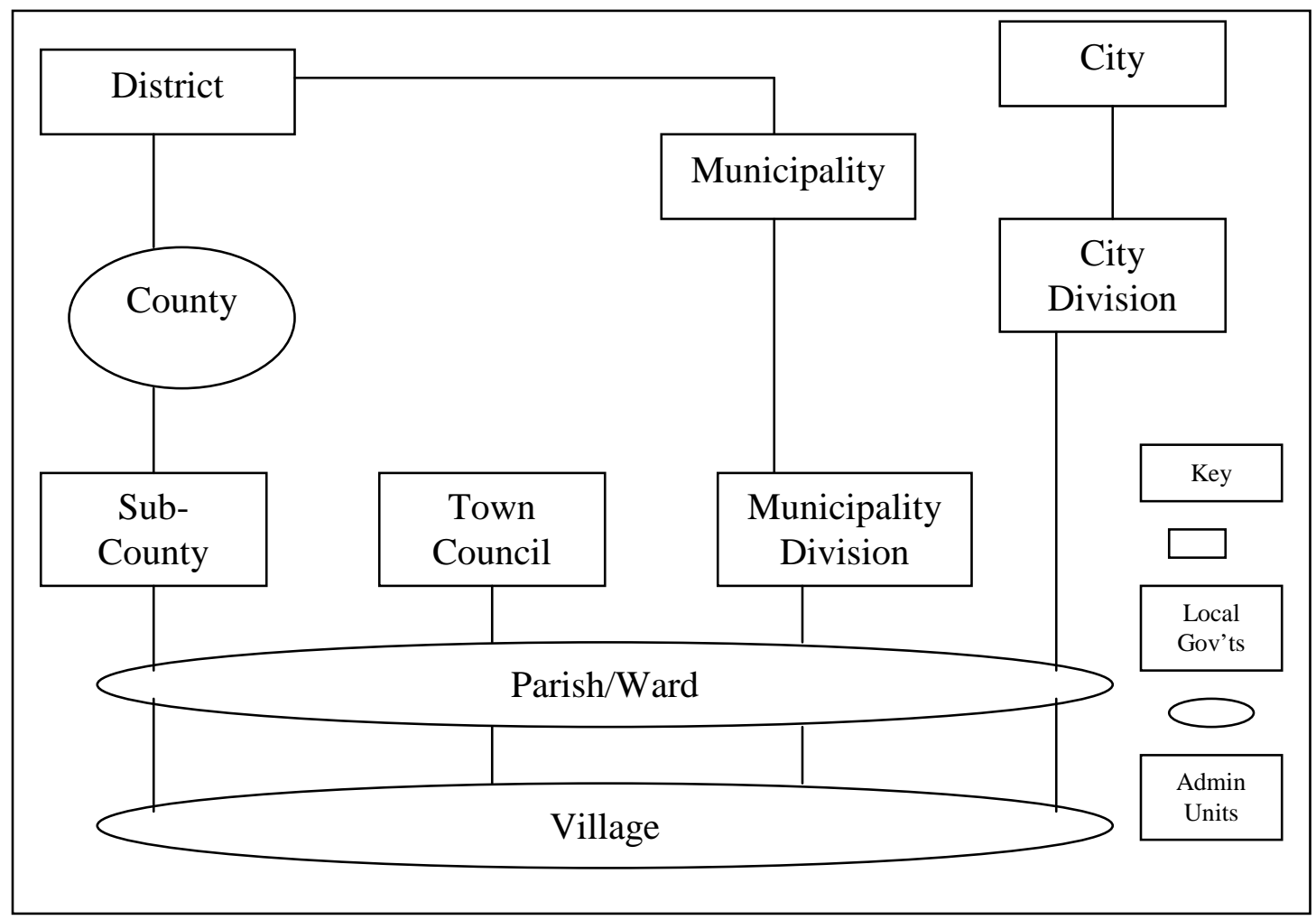

(Source: Ahikira 2007, p. 187)

The current government, the National Resistance Movement (NRM) gained power through force in 1986. Many women were involved in this struggle to get the NRM into power; this fact gave them strength in their argument to be included in the government. The insertion of women into the political structure was set up by allocating a third of all Local Council positions for women. At each level, village, parish, sub-county, division and municipality and district, women must hold a third of the positions (Bikaako \& Ssenkumbs, 2003). While this has changed the political picture from one dominated by men to one that brings women into the public sphere, there is some well founded criticism that sees this transformation as more symbolic then based in a true desire to change gender norms. Josephine Ahikira (2007, p. 14), a faculty member of Social Science at the Department of Women and Gender Studies, at Makerere University in Kampala discusses how there is concern that women were put in political positions simply as tokens of change rather then as symbols of real transformation. The author argues that women's 
involvement in politics has only reached the upper class and thus has not transformed the way in which the general population of women in Uganda interacts with the state (Ahikira, 2007). The struggle over land rights has served as an example of women's inability to protect and promote their rights through politics and the law.

In 1998 the Government of Uganda passed a new Land Act, the purpose behind the new set of regulations was to provide security of tenure through a demarcation and registration process of all the existing forms of land tenure, both formal and informal. The four forms of tenure are recognized as the following:

\section{Graphic 2: Land Tenure Descriptions}

\begin{tabular}{|c|c|}
\hline $\begin{array}{l}\text { Name of } \\
\text { Tenure System }\end{array}$ & Definition \\
\hline $\begin{array}{c}\text { Customary } \\
\text { Tenure }\end{array}$ & 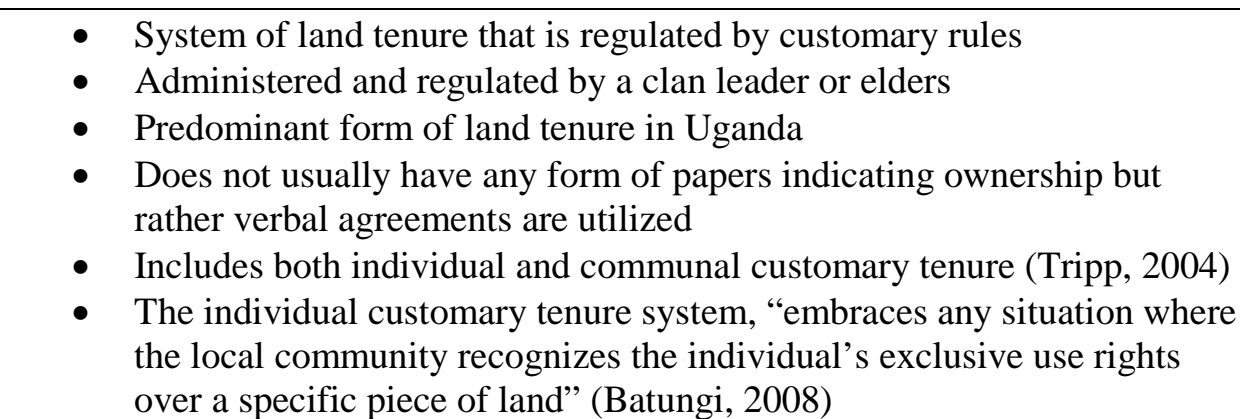 \\
\hline $\begin{array}{l}\text { Freehold } \\
\text { Tenure }\end{array}$ & $\begin{array}{l}\text { - The holding of registered land under the law, which states that the } \\
\text { owner has full ownership rights } \\
\text { - Most common form of tenure in the West }\end{array}$ \\
\hline $\begin{array}{l}\text { Leasehold } \\
\text { Tenure }\end{array}$ & $\begin{array}{l}\text { Involves a lease agreement between the lessor and the lessee in which } \\
\text { agreements are reached in terms of the length and conditions of the } \\
\text { lease. Lessee is usually the state and leases run form } 33 \text { to } 99 \text { years. }\end{array}$ \\
\hline Mailo Tenure & $\begin{array}{l}\text { - Mailo land tenure is the holding of registered land in perpetuity with } \\
\text { roots in the allotment of land pursuant to the } 1900 \text { Uganda Agreement } \\
\text { - Agreement between the Buganda clan in central Uganda and the British } \\
\text { individuals were provided land through the clan or lineage head, and in } \\
\text { turn these kings, family heads, or clan chiefs received freehold titles for } \\
\text { this land that they oversaw. (Tripp, 2004) }\end{array}$ \\
\hline
\end{tabular}

(Source: Tripp, 2004; Batungi 2008)

The passing of the Land Act resulted in the state law recognizing customary tenure under the state legal system, along with the other three forms of tenure. Due to the fact that eighty five percent of the land in Uganda was held under customary tenure, (Batungi 2008) the change in tenure regulation, away from this system had potentially large implications. Urban elite women 
took note of this and during the lead up to the passing of the 1998 Land Act women's groups utilized their new political power to rally around and promote the co-spousal amendment (Bikaako \& Ssenkumbs, 2003). The importance of this amendment was that it included a coownership clause, which would have made it so that all married couples would own the land they live on equally but as stated in the introduction the amendment was excluded at the last moment due to a procedural irregularity. Whether this was intentional or not is debated but how the amendment has been handled since has shown that the Parliament and the president are unwilling to pass the co-spousal amendment into law. This has left women in a position of having weaker rights over the land just as the country was moving into a time of land rights transition. Currently the co spousal amendment has been included in the Domestic Relations Bill, which has been in debate for over a decade. This protracted debate is due to its controversial content, which includes provisions on bride price, female genital mutilation, polygamy and marital rape. The bill is currently tabled.

The most important protection for women in the Land Act, thus, is the consent clause, which requires that before any sales transactions occur on land where a family lives, or from which subsistence is provided, the spouse and adult children should be consulted. This has the potential to secure women's tenure security but it is unclear how effective this has been. The reality is that without the co spousal ownership clause women are mostly viewed as witnesses to land ownership and not as an owner. They have the legal right to buy land but this only tends to occur in the upper class. For the average Ugandan women, her access to land is via her husband. Although the family owns customary land, the legal owner of the land is represented by the head of family, which in most cases is a male (Lastarria-Cornhiel, 2003).

When discussing the impact of the 1998 Land Act it is important to differentiate the law itself from the reality of how it has been implemented. The Land Act had strong potential to protect women's land rights, especially if it had included the spousal co-ownership amendment. While the Land Act includes an array of land titling systems, including Community Land 
Associations, which had strong potential to protect women's rights, the government has focused on freehold as the best means of securing land rights.

The Ugandan government's unwillingness to include women as equals in the land law represents a direct conflict with its recognition of the importance that women play in poverty alleviation. The government asserts that to achieve sustainable development gender inequality must be addressed (The Uganda Gender Policy, 2007) and recognizes that the lack of ownership of land by women retards development and contributes to poverty (Latarria-Cornhieal, 2003).

In sum, there is evidence which indicates that women's land rights have decreased through time due to promotion of freehold titling, combined with the influence of the free market system (Manji, 2006). During a time of tenure transition there is potential for tenure insecurity’s, in Uganda this has been exacerbated by the fact that politically the government is giving mixed signals surrounding women's role in society and is not taking proper action in terms of implementation of the Land Law (Adoko \& Levine, 2008). The government has acknowledged the benefits of women's political and social involvement, as a means towards alleviating poverty and promoting sustainable growth, (Ministry of Gender, 2007) while simultaneously being unwilling to provide women strong legal protection of their land rights (Adoko and Levine, 2008). While the political and academic debate continues on tenure security, titling and development, we have little knowledge as to how this land transition is playing out on the ground in Uganda. This paper begins to address this gap in the literature. Specifically, it explores the impact of the Land Act in rural Uganda in the last decade and asks the following questions: How has the Land Act impacted women's lives, and what are their opinions about it? How is it being utilized? What is its effect on customary systems? What are women's concerns and perspectives surrounding the land rights issue? What forms of tenure do women prefer and what do they see as steps forward? 


\section{Methodology}

This paper utilized three main research methods: 1) review/archival analyses, 2)

observation and 3) interviews which included two categories: elites and rural female farmers. For the archival research and literature review, the researcher examined current and past relevant literature as well as a wide array of documents such as district plans, laws, and locally produced studies on land issues. To understand what women in rural Uganda know about the Land Act, and to gain insight into women's reactions to it, fieldwork was conducted in the Kanungu District in Southwestern Uganda. The fieldwork was conducted in the summer of 2009 and consisted of: observation, which occurred through field visits to local farms, key informant interviews with local elites, as well as semi-structured interviews with female farmers. The data reported in this paper came out of fieldwork conducted during July and August of 2009 in which the researcher conducted four key informant interviews and 29 semi-structured interviews with local female farmers. The elite interviews were conducted in English at the local council buildings in Kanungu. These interviews provided a broad overview of the issues surrounding gender based land issues and provided the researcher with an understanding of women's land rights and the Land Act from the elite perspective. The interviews with the local female farmers took place with the support of a research assistant who provided interpreting skills as well as general support and knowledge of the area. The assistant was the daughter of the Local Council Chair Person (LC5) but was not well known in the area due to the fact that she did her primary and secondary schooling elsewhere. The interviews were conducted in Luchiga and took place in a variety of locations including a small salon, a church, a local council building, and a women's co-op meeting center. A convenience sampling was utilized and meetings were arranged through the LC5, thus while the sampling was not random it was still significant in size and variety of age, class standing and education. One potential limitation of the sampling was the prevalence of Anglicans; while this is a potential bias the researcher did not feel that this hindered the study. The interviews were documented through notes and voice recording. These were transferred into 
written form through transcription. On the completion of the transcription, themes arose out of the date through close reading and content analyses.

\section{Map 1: United Nations Maps of Uganda by District}

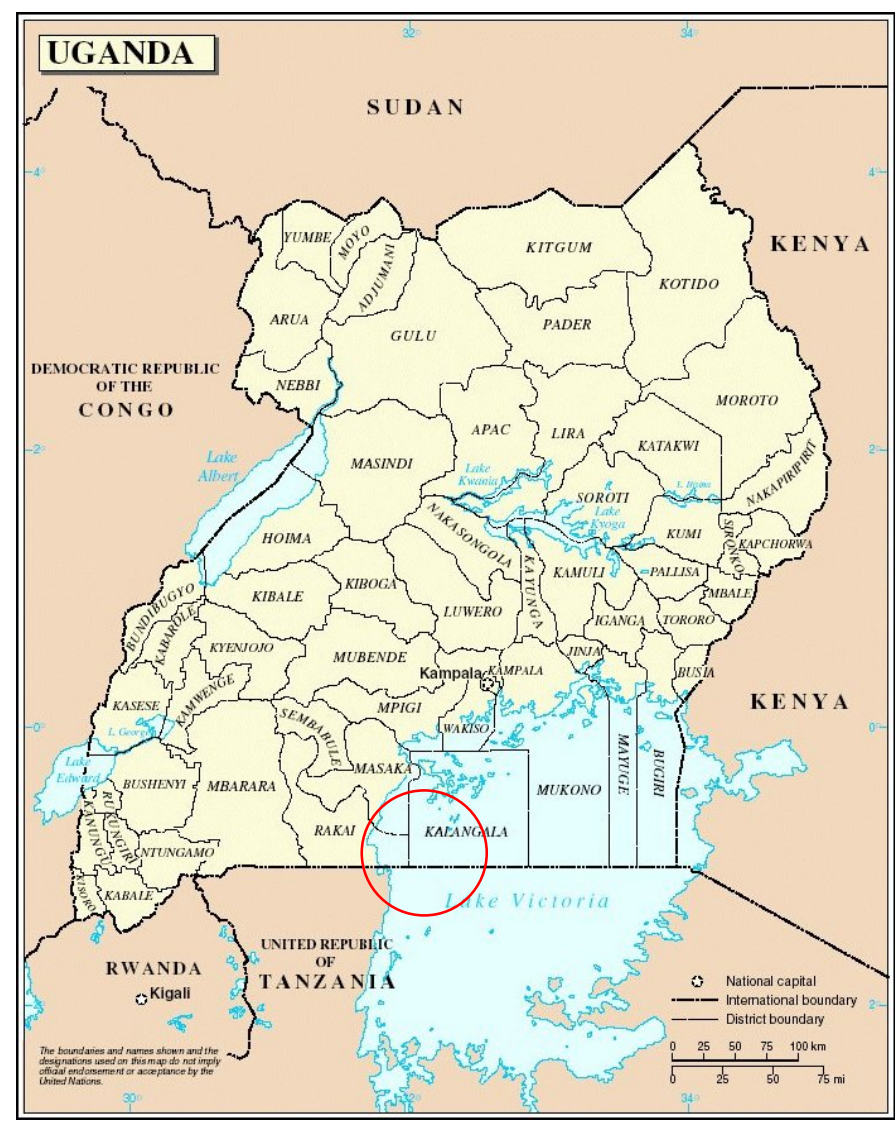

(Source:http://www.ugandamission.net/aboutug/map1.html)

\section{Map 2: Kanungu District}

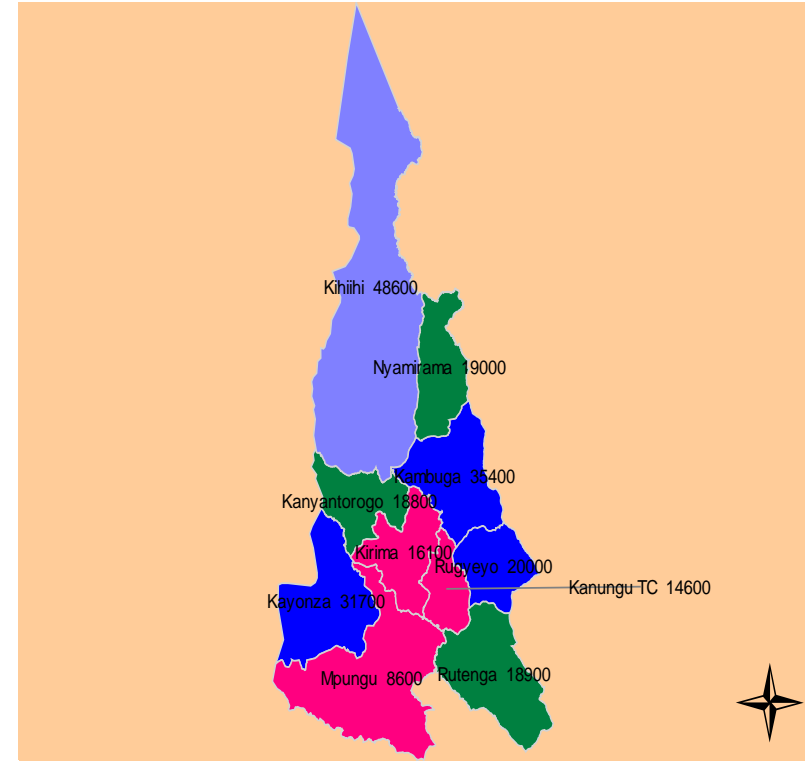

(Source: Kanungu District Local Government District Development Plan, 2009) 


\section{Research Setting}

Kanungu District, the setting in which the research was conducted, is a relatively new District having been established in July of 2009. It is comprised of 9 sub counties, 508 villages and 46 parishes (see graphic on p. 16 for structure reference). Kanungu District is located in the southwest corner of Uganda, just south of the equator and is bordered by the Democratic republic of Congo on the west, Kabale District on the southeast, Kisoro in the south and Rukungiri in the north and east. The District lies in the fringe of the Western Rift Valley, receives approximately $1200 \mathrm{~m}$ rainfall that is well distributed annually but slightly more concentrated during the months of March- May and Sept-Dec. Most of the population of the District is categorized as rural as only 14 percent are considered urban dwellers. Subsistence agriculture is the major economic activity and the main form of land use, with 60 percent of the District $(1,228,28 \mathrm{sq} \mathrm{km})$ being utilized as small-scale farmland. Land is held predominantly through customary practices, although a small portion is held under leasehold by a few well off farmers (Kanungu District Local Government, 2009).

\section{Table 2: District Profile}

\begin{tabular}{ll} 
Category & $\#$ \\
Percentage of working persons in agriculture & $81 \%$ \\
\hline Average household size & 4.7 \\
Average population density per square kilometer & 187 \\
\hline Average family land holding & 0.4 hectares \\
Total Population & $231,700(2008)$
\end{tabular}

(Source: Kanungu District Local Government, 2009)

Kanungu District has a three-year development plan from 2009-2012. This plan provides data on the current state of affairs in the District as well as many ideas and strategies for improvement. Two main issues that were addressed in the development plan were land use planning and gender equality. Land is the base of the economy in this region with much of the future development 
plans focusing around agriculture (Kanungu District Local Government, 2009), Kangungu is an agriculturally rich area with good rainfall. While most prospective development focuses around agriculture, there is also the acknowledgment of the problem of shrinking land plot sizes, land fragmentation, as well as soil degradation, and the need for more land conservation and environmental awareness. In terms of gender equality, the District Development Plan focuses on the need to have equal opportunities between men and women as a key part of alleviating poverty. The plan highlights the persistence of gender norms that keep men in control of the family resources while women are responsible for keeping the family life running smoothly and have little time for outside activities to improve upon their situation. The unequal balance of resources results in the fruits of these resources not being utilized for the whole family. As the plan states,

The division of ownership, access, and control over resources between women and men contributes to poverty in the household because it leads to resources owned by or entering the household not being used for the benefit of the whole household. (Kanungu District Local Government, 2009, p. 69)

The Development Plan highlighted three main factors that have contributed to land issues: rapid population growth, land fragmentation, and soil erosion. For the last three decades the population has been growing at an annual rate of 2.1 percent (compared to a national growth rate of 3.3) thus growing from 118,658 in 1980 to 226,100 in 2007, equaling a 75 percent population increase over the last 27 years. Inheritance practices in the area include the parent's distribution of their land between their children. Previously distribution was just between the sons but the norm is changing and parents are starting to include their daughters in this distribution process. As the population increases the land is becoming increasingly fragmented. The Development Plan states, “The land is highly fragmented due to traditional practices of inheritance and high population density” (Kanungu District Development Plan, p. 10). With high population growth and land fragmentation comes the issue of land degradation which is occurring 
due to poor agricultural management practices, such as: bush burning, overgrazing, loss of vegetation due to clearing for farming, and wetland drainage. The combination of these issues has led to a high occurrence of land disputes and instances of land grabbing in the District.

\section{Table 3: Agriculture Activities: Broken down by gender}

\begin{tabular}{ll}
\hline Key ACTIVITY & Gender of person involved \\
\hline Purchasing/owning land & Men \\
Planning for land use & Men \\
Tilling of land & Mainly women \\
Procurement of seeds and other inputs & Men \\
Planting seeds and weeding & Women \\
Harvesting & Women and girls \\
Attending agricultural workshop and & Mainly men \\
meeting & \\
\hline
\end{tabular}

(Source: Kanungu District Local Government, 2009)

Women are mainly involved in subsistence agriculture, which involves producing food for the family, whereas men are involved in producing commercial crops such as coffee, tea, and tobacco. In Kanungu as elsewhere men also have more control over the resources, in most situations they have ownership of the land and they make decisions surrounding possible sale of the land. While the 1998 Land Act included the Consent Clause, which requires that both spouses give consent for the sale of land, this is still a point of contention. The Development Plan acknowledges that the Consent Clause has not taken root and it states: "In many house holds, land is owned by men. All decisions pertaining to use, transfer, mortgage or selling are made by men” (Kanungu District Local Government, 2009), while simultaneously "Women can only till the land and produce mainly food for home consumption” (Kanungu District Local Government, 2009, p. 63). The plan acknowledges that this unequal balance of power over resources between the genders holds the district back, in terms of forward movement towards development and a fully productive society, 
Gender is an equity question asked on the realization that if development is to be made, equal participation between men and women should be ensured (Kanungu District Local Government, 2008, p. 60)

\section{3: Research Findings}

My research examined women's ability to access land, with a specific focus on whether the 1998 Land Act has affected that access. Of particular interest was women's awareness of the land law, their understanding of their rights, whether they have a preference for the traditional or the new freehold system, and what informs their preference. The over arching research questions are: How do women perceive their land rights? What strategies have women developed to facilitate their access to land? Do women believe the 1998 Land Act inhibited or aided their struggle for land?

To answer these questions I conducted four key informant interviews and 29 interviews with female farmers in the Kanungu District. The key informant interviews were conducted in English, thus the quotes are in the first person. The subsequent interviews with the rural female farmers, were conducted in the local language and required a translator, thus the quotes are in the third person. Some of the quotes are grammatically incorrect, due to the fact that the researcher felt it was important for authenticity to leave them in their original form. All of the interviews followed the same outline, starting with simple questions about family, including family size, marital status, and education level as well as a bit of family history. The next set of questions focused on day-to-day life, including a ranking of most important needs, and how time was spent. The third set of questions focused on land issues, asking where the interviewee lives, how they came to live there, and what type of agreement they have regarding tenure security and use rights on the land on which they live and cultivate. Lastly the interview format touched on issues around preferences for land tenure, asking whether the interviewee preferred the customary/traditional methods of tenure or whether they preferred to utilize the freehold/law tenure system. 
Key Informant Interviews

To understand the current context of land issues in the District, I conducted interviews with four key informants prior to interviews with rural female farmers. The key informants were local elites in the district who held a range of public positions; three were female and one was male. The researcher felt that interviewing the male elite would provide breath to the research; also the position held by this individual was considered an important point of view and source of information. Positions held included: District Councilor, Secretary for Land Finance and Administration, Secretary to the Land Board, and Senior Mobilizer in the Resident District Commissioner's office. The interviews were conducted in a more discussion-based manner; they adhered to the general structure of the questionnaire but followed a more organic pattern and included many additional questions (See appendix A). The main topics covered were: 1) implementation and awareness of the Land Act; 2) land scarcity and insecurity due to marriage issues; 3) and gender norms. Many of the opinions and themes that arose during the key informant interviews are representative of the themes and ideas that were laid out in the District Plan.

When discussing the 1998 Land Act with the key informants all four had faith in the new laws to protect the land rights of Ugandans, including women. But simultaneously they had some strong critiques of the implementation process including its slow pace, lack of awareness, and inaccessibility for the average Ugandan in terms of cost of a land title. All of the key informants were well versed in land issues and felt that land was a very important topic because of its direct connection to quality of life for all. Also, all four stated that the empowerment of women and girls was important to the development of their District and the country as a whole.

...land is directly correlated with the ability to provide schooling for the family and be able to pay school fees, because when you have land and are growing food then you reduce expenditure, automatically then you have an income for school fees. (7/23/09 - \#1) 
...we have put emphasis on girl's education... Because you

know when you educate a girl you educate a nation. So we

know that at one time when we get everyone getting

educated it will bring change to our society. (7/23/09 \#3)

\section{Implementation and awareness of the land law}

All the key informants identified difficulties with the implementation of the law including: lack of awareness at the community level, insufficient financial support from the government, and unfeasible cost of titling process for the rural individuals in the District applying for a title. Interviewee 2 (7/23/09 \#2) acknowledged a lack of titling applications in the District. The interviewee estimated that the Land Board received about ten a month, and stated that very few of them were from women. The interviewee estimated that out of one hundred applications two would be from women, and these applications tended to come from women's groups, not individuals.

All interviews explained the low level of titling by indicating that the process to get a title is extremely expensive. Interviewee 2 (7/23/09) estimated the cost to be about five hundred dollars for an individual to go through the full titling process. The interviewee stated: “To do land titling for one acre could cost you five hundred dollars, so you can see its quite a lot and if it (the land) is off of the road, thus lacking infrastructure, it could be as much as one thousand dollars” (7/23/09 \#2). In response to questions about the impact of the cost on titling applications the interviewee stated, "of course it has serious implications, it has deterred many because raising five hundred dollars is quite a lot” (7/23/09 \#2). The cost of the titling was seen as a huge obstacle that would need to be surmounted if the government was truly dedicated to a private, freehold tenure system. Interviewee 2 (7/23/09 \#2) also discussed the lack of financial support from the government to facilitate the local land committee. Land committees are key administrative component in the Land Acts. The local level committee provides a report of any land dispute to the District Land Board, and is the first step in any title application process. Currently no central government funding is provided, thus the local communities have made due 
by acquiring financial support locally through fundraising. Interviewee 2 brought up a possible solution to the problem of how inaccessible the land law is, suggesting decentralizing the title application process. This would bring the administrative office to the local District level (form Kampala, the capital city). This would greatly reduce the cost for the individual in terms of travel costs and also hopefully raise awareness. Interviewee 2 saw this as a necessary step if the government was truly dedicated to the implementation of the Land Act.

All the key informants shared the view that in rural settings the Land Act was not understood as thoroughly as in the urban areas. There was an awareness of the fact that in the more rural setting it was more difficult to utilize the land law, more specifically all informants stated that even within the District none of the title registration applications came from the rural areas. The reasons for this were thought to be the increased cost to have the land survey due to difficult access from main roads as well as a lack of understanding of the land law. One interviewee touched on how few land title applications they were receiving due to these different obstacles saying: “The process is very bureaucratic, very difficult to go through, very expensive...” (7/23/09, interviewee 2).

All four informants agreed on the need for more sensitization on the law. In response to a question about awareness of the land law, interviewee 3 stated that, “it isn’t enough, it can’t be enough, there is a lot to be done, so far as sensitization and mobilization” (7/23/09 \#3).

\section{Land Scarcity}

When asked questions about land, inheritance and family, all of the key informants touched on the scarcity of land, resulting in smaller plot sizes and the inability to distribute to family members in the traditional method.

“...want to see my children owning their own property.... would be very sad if they had to go back and fight for their family land that is not there.” (7/23/09 \#3)

This deeply affects the norms of inheritance practices and pushes families to promote alternative forms of accessing land. Children are encouraged to procure their own land through 
purchase or rental because they cannot rely on inheriting land from their family to support them. Arising frequently in my interviews, this was a topic of high concern in the area. Another factor in the change in inheritance practices is the push to include females within the family land distribution process. While the government is promoting this it still is not the norm. If girls are included they tend to have to share one piece while the male counterparts each get their own piece of land. All of the key informants were included in the distribution of their family's land. Out of the three females two shared a plot with their other sisters and one believed that she would get her own plot, under her name but was unsure as the distribution had not yet occurred. They all acknowledged that it was the norm for the boys to get their own piece of land and for the girls to get one piece to share. When asked about inheriting from their parents, one of the interviewees stated,

"I will have the land in my name I think but normally most parents distribute the land between all of the boys and then the girls all share one piece of land. Whether you are five or ten you co-own but the boys get their own.” (7/23/09 - \#1)

Insecurity due to Transitioning Tenure System and Gender Norm

All the key informants still saw the need for improvement in women's rights. While they all thought the Consent Clause was beneficial, they felt that without co-ownership there is and will be a lot of insecurity of tenure for women. Interviewee 1 (7/23/09 - \#1) talked about how they were fighting for equal rights so that in the case of divorce, which is reportedly a common occurrence, each partner can leave the marriage with their equal share of the property, which they have bought together. As interviewee 1 said:

"But we are fighting for females to also be able to access land. When a husband is buying land let it be that we both buy the land and own it together. So for us now as women, what do we want? We want to own land. Because you know, (well you are not married), but over time things change and you will find that your husband is chasing another wife, you can no longer stay together and you had better go. When you have toiled together for fifty years and you have bought the land together, but now that the agreement says that Joe has 
bought Justine is a witness, then you go empty handed. So what we want is that we buy jointly and we own jointly. So that if marriage issues change then we share, you stay with your part and I stay with my part” (7/23/09 - \#1)

When discussing women rights, all of the key informants brought up the Domestic

Relations Bill. They discussed how this bill had the potential to make a large impact on women's security, both in terms of land tenure as well as gender equality because of its provisions that include co ownership (thus affecting wives inheritance) and the legislation of cultural norms such as bride price and marital rape. The bill has been tabled, and there is skepticism about when or if it will be passed. All the key informants expressed a desire as well as a need for change in cultural norms in all sections of society. However, while they have changed within the upper class and well-educated parts of society, this transformation is slow in reaching the average Ugandan.

"The cultural norms are no longer there, just down in the grassroots where the women are not yet empowered, but where the women have reached empowerment economically, socially and politically the cultural norms no longer work”(7/23/09 \#3).

“Believe that women's ability to access land will keep improving because not even ten years ago people thought that women didn't own land, because we have a paternalistic society because women come to husband's land without anything. What did you come with? You came with nothing, so she doesn't own anything. But now they own together, the wife has ownership where she lives (through consent clause) so it is an improvement. Think that Domestic Relations Bill will help move forward.” (7/23/09 \#2)

The key informant interviews set the context for the next round of interviews with rural women who are most affected by cultural norms around land and inheritance. They provided insight into the government position on women's land rights as well as the individual's perspective. These interviews gave the researcher insight into the perspective of the upper class and well educated within the District. The underlying message was that there was faith in the possibility of the Land Act but that currently it had not been properly implemented. A key concern was enhancing 
women's access to land, which was expressed in both the need to change the law as well as cultural norms.

\section{Findings from Interviews with Local Female Farmers}

To conduct the main interviews with the local female farmers the researcher made contacts through local government and local elites who identified community members to act as a liaison into differing sub-counties. Within the sub county the local community member would gather a group of women who were willing to share their stories. All of the women were involved in subsistence farming, but were a mixture of different educational backgrounds and age. The sampling came from three sub-counties: Kihihi, Kirima and Rutenga as well as from the Kanungu Town Center (see map on p. 17).

The following are the main themes that arose during the interview process: 1 ) lack of awareness of the Land Act; 2) insecurity due to marriage issues and inheritance practices; 3) utilization of alternative and informal channels to access land. The overarching theme that incorporated all of the sub themes was the importance of land access for women's lives. I heard repeated statements how daily existence is directly tied to their land and because of this they feel having access to land was a necessity for survival. For most of the interviewees it is their land that provides food for themselves and their family and provides the space for their home, thus it is their land that sustains them. Land is seen as such an important part of life that one of the interviewees indicated that everyone should have a small piece of land because she knew that it was her small piece of land that kept her going. She felt that everyone should have at least that basic piece for survival. Access to land is representative of an individual's opportunity in life and the power they hold in the community. When asked about the necessity for women and men to own land equally, one of the interviewee’s (7/27/09, \# 2) stated that “... it is important because ideally they are supposed to have the same opportunities in life and here (Kanungu, Uganda). Land is the base measure, the beginning point of what you are going to be. So the same piece of 
land kind of means equal rights or power”. Women had strong opinions about land's importance and felt that having equal ownership between women and men was necessary and would be extremely beneficial. Example statements include:

All of them are human beings and because of that they should all be entitled to the same opportunities in land (7/25/09 \#1)”;

(Equal ownership is) Important because the women usually has donated to the buying of the land so it is only fair (7/28/ 09 \#1);

Its very necessary because these days a majority of the women are contributing to the money that they use to buy the land so because if that they deserve an equal chance to be the owner (7/25/09 \# 15).

Women understood that owning land equally would be beneficial for women's land access and security as well as for development; some saw that it had the potential to bring cohesion in the home, while also expressing fear concerning the possible conflict that would arise when attempting to navigate equal ownership. An exemplary expression of this perspective:

(Equal ownership) "It's important because it brings harmony in the home and can be very developmental because land is a valuable asset, so any decision around it is a big decision. So if they have the same opportunities they can make the same decisions to better themselves, but if the man has selfish motives and you don't have an opportunity to stop him it can cause a rift" (7/27/09 \#3).

Women's desire for equal rights over land revolves around the aspiration to keep the land for their children and to be able to pursue their development ideas. Many women expressed the strong conviction that women are more focused on development than men, and that with the unequal rights over land women are not able to engage in their ideas for social and economic advancement due to male control. When asked about how they would most like to access land women favored the customary system; they felt that the customary could provide better protection due to its connection with the community. 


\section{Lack of Implementation and Awareness of the Land Act}

During the interview process the interviewees were asked a series of questions related to the Land Act, from these responses an obvious lack of awareness and understanding of the land Act emerged. This also ran parallel with the apparent lack of implementation, which leads to women's inability to utilize the land law to protect their land interests. The research found that of the 29 interviewed, 16 said that they had heard of the Land Act but most were vague on the specifics. When asked directly if they had heard of the Consent Clause, 21 women said that they had heard of it but many were not sure what it said or how to make use of it and this left them in a vulnerable position. As one interviewee expressed: "they need to sensitize people to their rights because they might have a vague idea of what it is about but since they don't know they suffer at the hands of the men” (7/24/09 \#1).

Inability to uphold the law, issues of domestic violence and general disregard for women’s legal rights, were common topics. Women have little trust in the law's ability to protect them, and law and legal process were looked at as something outside of the community, foreign, and difficult. Many women felt that it was ineffective and that men would do what they wanted regardless of what the law says. Women made statements about the man doing what he pleases and there was a lack of possible effective recourse. One of the interviewees had a personal story of intense struggle that illustrated women's inability to utilize the law to protect them: "Husband rents some of the land to get money to drink, so if it were up to her she would end that. Also he sells some bits without asking her” (7/24/09 \#2). She knew that a law was passed that required the husband to get the wife's consent to sell the land but she did not know what the law was called and stated that if she said anything then he would simply beat her up until the point of hospitalization. She knew this from attempting to hold him accountable by getting an injunction from the LC1 (District level government), an incident which ended with her in the hospital. While this was acknowledged to be an extreme case, similar types of scenarios were considered to be a common occurrence. There were a lot of comments about the government's inability to uphold 
what the law says, "As much as there is the government policy which says that they need to consent, many women fear their husbands so they are bound to do it under duress, so in the end the man has the say with what will happen with the land” (7/27/09 \#2).

The issue of women's inability to exert control over the land of her husband is highlighted in the case of the husband's death. In many cases the husband's family members lack any respect for the woman's right to that land. This can result in the family attempting to take the land; one such case was gathered during the interview process. The researcher interviewed a woman whose husband had been killed by his brothers over land disputes. The brothers were still threatening her and her children because they would inherit the land once they turned eighteen. She stated “ here as a widow you can’t sell land when the children are young but they (her brothers in law) are saying that they will kill them before they get old, so that way she won't have title to the land” (7/25/09 \#3). She was trapped between the laws: the customary system was not protecting her and she was unable to access the formal system set up by the Land Act. Unable to protect herself she left her land and moved back to her parents with her children.

There were some more hopeful perspectives that saw improvements in women's rights while simultaneously acknowledging that there was still a long way to go in terms of women being aware of what their rights are. One of the interviewees discussed the improvements over time saying:

If she compares her generation and her mother's generation, her mother's generation never had any say and the men aren't very developmental so they would just squander the land, they would sell it just to drink, but now her generation ...women have rights and know them but not of all women know so there needs to be more sensitization (7.29.09 \#2).

\section{Utilization of Alternative and Informal Channels to Access Land}

During the interview process the interviewees were asked a series of questions about the land tenure method they utilized as well as which one they preferred. From the responses a theme arose that demonstrated the utilization of alternative and informal channels of land access. 
Through discussing both what form of tenure the interviewees had and also what methods they used or would use for handling any sort of land dispute the researcher was able to gather data that indicated a strong preference for the customary land tenure systems in the area.

Utilizing the customary tenure system rather then the freehold was accepted as the social norm within this area, and in the cases where interest in a title existed the cost was preventative and therefore unattainable. Most of the women interviewed thus were utilizing the customary system. The researcher found that out of the 29 interviewees, 20 of the women specified that they had customary agreements for their land, while only three had a title. Not having a title but rather utilizing the customary land tenure system was accepted as a social norm. Interview (7/27/09 \#2) stated, "she has not thought of getting a title because it's the norm not to have one, she doesn't think it's a big deal. Most people she knows do not have one”. In the cases where women had thought of getting a title, cost was targeted as prohibitive, along with a general lack of need. Statements were made such as the following: "It's expensive, costly, they have to pay surveyors: it’s a long tedious process” (7/24/09 \#4); “She would want to get it but she has asked around and it is very, very expensive, she knows that it is very expensive” (7/25/09 \#4); "She knows that it is very expensive and that alone discourages her from even trying, because of that she doesn't want to go through the whole process, she doesn't have the money” (7/25/09 \#5).

In terms of how women would like land to be governed, women showed a strong preference for employing the customary system through utilizing the elders in dispute situations or when asked to speculate about possible changes in land access and control. When asked about which method women preferred to utilize for resolving land issues, 17 of the 29 women stated that they would prefer to go to the elders over the law. Most women felt that the elders know the area and the land well and thus were better suited to make decisions regarding it. They felt that overall the community respected the decisions of the elders more because they were more active within the community-it was the elder's opinion that was considered to be more important. When 
asked about whether interviewees preferred the customary system or the law to make changes in how land is accessed and controlled, the responses included the following:

She would rather go to the elders because they give spot-on (on the spot) decisions, than the law which takes forever; she doesn't think the law can help her. (7/25/09 \#1)

She would go to the elders first because they know the land, they were there when you bought the land, they will stand by you when you go to the LC level, they know the land and the procedure so it's important to go to them first (7/25/09 \#5)

They would understand the land better and the villagers respect their decisions more and the people that she would possibly have a dispute with would respect their decisions more (7/25/09 \#6)

A few women did show interest in making use of the new Land Act. Out of the 5 that expressed interest in utilizing the law, two of them felt that both the law and the customary system should be utilized. All of them, while expressing interest in utilizing the law, also expressed skepticism about its ability to be effective. One example is interviewee (7/24/09 \#1) who stated that she would utilize the law when given the choice between the law and the informal tenure system but when answering a question about the government formally recognizing rights, she said "Even if the government gave them (women) the right, when their husband or someone else locally did not want them to do it locally then the government probably wouldn't be there to help” (7/24/09 \#1). Another woman who expressed interest in the law had the belief that both the elders and the law should be utilized. She said "It's important to look at both because if you go straight to the law the elders eventually will know what you are up to and eventually it always come down to the elders, use both” (7/29/09 \#2). While another also felt that there was a need for a combination of the two that stressed a bottom up approach. She said:

"Ideally you need to use a bottom up approach because its more effective, so you start with the elders because they know what is happening but in the event that they don't side with you then you always have a recourse, you can go to the law because they are not the same people as the elders, the law is the alternative but if she wanted to change something she would use the bottom up approach” (7/29/09 \# 3) 


\section{Women's Focus on Development and Future Generations}

The last theme arose not through a specific set of questions but rather emerged throughout the whole interview process and was repeated extensively in different manners but the over arching message was that women see themselves as the force behind development. Women see themselves as the ones that need to take action to move forward, they are the "developmental minds/brains”, and they feel that it was their duty to keep their land for their children, protecting it from anyone who would like to sell it. In connection to their desire to keep their land for their children, women have an intense opposition to the transference of land. The term that was repeated with high frequency was “developmental”, for women this means focusing on selfimprovement for the family and development that includes focus on the future generations.

A recurring point that kept coming up throughout the interview process was the plethora of statements that depicted women as more inclined towards development. Women believe and acknowledge that they are the ones with the more "developmental brain/mind”; they are focused on education for their children, opportunities for financial stability, as well as opportunities for self-improvement. In contrast, there is a strong belief that many men make rash decisions, sell land for bad reasons, use money to drink and do not think of the future, or the family. One of the interviewees said: “The women are more developmental, they are the ones who start unions and they are the ones that are very keen on their kid's education. The men are the ones who just go eat meat and drink beer,” (7/27/09 \#4). They also feel that men need to be superior and thus see problems as a sign of weakness, which causes them to make rash decisions that can hurt the family. On the other hand they expressed that women are comfortable talking about their problems, so they will share and discuss the issue and through this look for the most probable answer. "You're probably smarter than he is and appropriate you want to make decisions concerning the land but you can’t because ultimately he also has to agree for example like if you had a problem he would probably fix it quickly by selling the land”. 
There is a strong awareness of the increased pressure on land, because the land that is gained through inheritance has been fragmented to the point that it is not enough to provide for the family. People are forced to rent or look to buy other land to have enough to live on and farm. Interviewee (7/25/09 \#7) stated that “ the one (farm) they have is not enough” and thus they wanted to buy a piece of their own, while another women stated that "the land that they have is not big enough so she rents land to farm...” (7/24/09 \#4). It was common to live on one piece of land and then to farm on another piece of land.

With the increased pressure on land, combined with a perceived increase in rash land sales, there is urgency and potency to the desire and need to maintain and defend the land that one had. One of the interviewees talked about her family's method of increasing protection even within the family. The interviewee described a system that her parents had devised in which an agreement had been made within the family to give each other first right to the land, when one of them wants to sell. The parents demarcated the land for the children but kept the documents, this way the children are unable to sell the land without parental consent and the family gets first priority. When asked about the effectiveness of this arrangement, the interviewee stated that she believes that it is beneficial because it prevents the inconsiderate siblings from selling the land they were given and then coming back for more (7/24/09, \#1).

The intensity of the fight to protect the land is palpable at times. Women describe it as an obligation and feel that they need to have equal rights so as to protect the land for the future generations.

\section{4: Conclusion}

The interviews in this study illuminated the fact that there was a lack of awareness of the Land Act and that a decade after its passage women are still either unaware of the Land Act and /or prefer not to utilize it. What arose as the main instigators of land insecurity for women in the area was the transitioning of gender roles, family land disputes and increased land pressure. These 
issues were exacerbated by the lack of possible recourse for women when conflicts arose.

Overall women preferred to utilize informal channels to access land but also saw the strength in combining the utilization of the formal with informal tenure methods. Whichever method they preferred, all women saw land as imperative to their well being and viewed themselves as the strength behind future development.

Throughout both the elite and rural female farmer interviews, there was extensive discussion about the transformation of women's role in society. Women expressed more concern over women's equality then over the means of land tenure. This concern seemed very practical because as the interviews illustrated gender norms are an overarching issue that impact many different aspects of life including land tenure. Women are working to be viewed as equals, in part because as many stories illustrated, without more socially excepted norms of gender equality, men will do what they please with the land regardless of the tenure system.

The other key factors affecting women's tenure insecurity were increased land pressure and family disputes both of which seem to be deeply affected by gender norms. As land becomes more fragmented and the need for additional plots of land is common, the need for access to land through ownership or inheritance is increased. This increased pressure on land seems to be leading to land disputes between neighbors and within families. Women's inability to protect their land seems to take place quite often within these dispute situations. Many women did not trust the law to protect them but preferred to utilize the elders, despite the fact that in many cases the elders were unable to protect them and their land.

A local organization called the Land Equity Movement of Uganda is responding to these issues of land tenure insecurity by calling for the integration of the two systems of land tenure regulation. They see the need for the state "to integrate the customary justice system with its own” (Adoko \& Levine 2009), in hopes of being able to better protect women’s land access. Promoting a system that integrates customary tenure forms with the state regulated system may 
increase land security by bridging the gap that is being left in the transition between the two systems of tenure.

Through this investigation of the impact and awareness of the 1998 Land Act, it became clear that creating a titling system when there is no means of implementation leave us unable to truly judge what the potential could be for this system of tenure. Rather it gives us the opportunity to see that in this time of tenure transition there is confusion, loss of land, and high levels of insecurity for women as well as the population as a whole. There needs to be a shift towards a system that actively incorporates women, for as the research noted, they are the ones that are looking for productive opportunities to help better their situation in life. Rather than looking towards titling as a means to alleviate poverty, improving women's roles need to be prioritized as a means of meeting the average Ugandan basic needs. While it is wonderful that women have been empowered within the political structure, without the equal protection of women's rights to land political empowerment falls short in terms of improving women's standing in society as a whole. Women need to be politically, socially and economy empowered if we wish to see movement towards viable poverty-alleviating development. 


\section{References:}

Adoko, J. \& Levine, S. (2008). Falling between two stools: How women’s land rights are lost between state and customary law in Apac District, northern Uganda. In B. Englert, and E. Daley (Eds.), Women’s land rights and privatization in eastern Africa (pp.101-.120). Cumbria: Long House Publishing.

Adoko, J., Levine, S. (2009, April 17). “Women land and development: In search of a titling to the family holding”. The Guardian Weekly.

Ahikire, J. (2007). Localised or localizing Democracy: Gender and the politics of decentralization in contemporary Uganda. Kampala: Fountain Publishers.

Batungi, N. (2008). Land reform in Uganda: Towards a harmonized tenure system. Kampala: Fountain Publishers.

Boone, C. (2007). Property and constitutional order: Land tenure reform and the future of the African state. African Affairs, 106/425, 557-586, doi:10.1093/afraf/adm059

Bromley, D.W. (2008). Formalizing property relations in the developing world: The wrong prescription for the wrong malady. Land Use Policy, 26, 20-27. doi:

10.1016/j.landusepol.2008.02.003

Bikaako, W. and Ssenkumba,J. (2003). Gender, land and rights: Contemporary contestation in law, policy and practice in Uganda. In L. M. Wanyeki (Eds), Women and Land In Africa: Culture, Religion and Realizing Women’s Rights. London, Zed Books Ltd.

De Soto, H. (2000). The Mystery of Capital: Why Capitalism Triumph in the West and Fails Everywhere Else. New York, Basic Books.

Deininger, K., Castagnini, R. (2005). Incidence and impact of land conflict in Uganda. Journal of Economic Behavior and Organization, 60, 321-345. Doi: 10.1016/j.jebo.2004.04.008

Englert, B., Daley, E. (2008). Introduction. In B. Englert, and E. Daley (Eds.), Women’s land rights and privatization in eastern Africa (pp.101-.120). Cumbria: Long House Publishing. 
Fortin, E. (2005). Reforming land rights: The World Bank and the globalization of agriculture. Social Legal Studies, 14, 147-177. doi: 10.1177/09646639051217

Kanungu District Local Government. (2009). Kanungu district local government three year district development plan. Kanungu, Uganda.

Landler, M. (2009, August 23). “A new gender agenda”. The New York Times Magazine, Retrieved from http://www.nytimes.com/indexes/2009/08/23/magazine/index.html

Lastarria- Cornhiel, S. (1997). "Impact of privatization on gender and property rights in Africa”. World Development, 25, 1317-1333. doi: 10.1016/s0305-750x(97)00030-2.

Lastaria-Cornhieal, S. (2003). Uganda country brief: Property rights and land markets. Madison, Wisconsin: Univeristy of Wisoncsin-Madison, Land Tenure Center.

Manji, A. (2001). Land reform in the shadow of the state: The implementation of new land laws in Sub-Saharan Africa. Third World Quarterly. 22,327-342. doi:

$10.1080 / 01436590120061633$

Manji, A. (2006). The Politics of Land Reform in Africa: From Communal Tenure to Free Markets. New York: Zed Books.

Ministry of Gender, Labour and Social Development. (2007). The national action plan on women. Kampala, Uganda: St Christian Graphics.

Ministry of Gender, Labour and Social Development. (2007). The Uganda gender policy. Kampala, Uganda: UNFPA

Nsibambi, A. (1998). Decentralization and Civic Society in Uganda: The Quest for Good Governance. Kampala, Uganda: Fountain Publishers.

Nyamu-Musembi, C. (2008). "Breathing life into dead theories about property rights in rural Africa: Lessons from Kenya”. In B. Englert, and E. Daley (Eds.), Women’s land rights and privatization in eastern Africa (pp.101-.120). Cumbria: Long House Publishing. 
Platteau, J-P. (1996). The evolution theory of land rights as applied to Sub-Saharan Africa: A critical assessment. Development and Change, 27, 29-86. doi: 10.1111/j.14697660.1996.tb00578.x

Sebina-Zziwa, A. J. (1995). Gender perspectives on land ownership and inheritance in Uganda (Res. Paper. No 16). Madison, Wisconsin: University of Wisconsin-Madison, Land Tenure Center.

Tripp, A. M. (2004). Women's movements, customary law, and land rights in Africa: The case of Uganda. African Studies Quarterly, 7, 1-19, retrieved from http://web.africa.ufl.edu/asq/ 
Appendix A- Interview Instrument

\section{Introductions:}

- (Start with name-general introduction)

- How are you?

- Have you had a good morning?

- How is your family?

\section{Explanation:}

- I would liked to start by telling you a little bit about what I'm doing. I'm interested in how women in this area gain access to land and what views they have on how land should be distributed and what should define ownership. I want to hear the personal stories of what women have done to gain access to land and how this has impacted their life.

- As a foreigner who lives in a city, I know little about the day-to-day life of women like you in this area. I'm interested in your story.

- (General thoughts----- including the work that you do, how you provide for your family, and how much time you spend cultivating land? Are you able to have access to land and if so through what means?)

\section{Descriptive:}

- Can you describe an average day for you- from when you wake up in the morning until you go to bed, what fills your day?

- How did you or your family come to live on this land/ or at this location in the Kanungu District?

- In terms of day-to-day needs, what is most important for you? If you could rank your three most important needs, what would they be and how would you rank them?

\section{Structural:}

- About how much of your day do you spend working you/your families land? 
- Is this production purely for your family's consumption or are some of the crops sold at a market?

- (Optional- depending on situation) How are agreements reached, when dealing with what will happen on the family land, such as what will be grown or in the case of it being sold who would make this decision?

- (Optional- depending on situation). What sort of agreement do you have with the owner of the land that you cultivate?

- So earlier you told me a bit of your family history and how you came to live in this area, could you take me through step by step process of how you acquire this land? What methods were used?

o (if they express struggle-focus in on key issue)

- Have you seen other women have similar struggles?

- What sort of action have you seen other women take in similar situations?

- How are women able to help each other in these situations?

- Do you know about the 1998 Land Act? (Probe: The Amendment to include co-spousal ownership in the Land Act? )

o (If Yes) What do you know about it? Do you believe that this would have been beneficial to women?

o (If No- briefly explain the Land Act and then ask previous question)

- Do you think it is necessary for women to equally own land? (Probe: That is, for the government to formally recognized women's land rights? Do they feel adequately covered by informal channels?

- Do you think a law like this-requiring women to have equally recognized rights-is important, somewhat important or not at all important for Ugandan women? 


\section{Contrasting:}

(If they see issue)

- What differences do you see between the over all struggle for land in Kanungu and the specific issues that women face? Do women face different issue, is it more difficult for women, or is the struggle the same for everyone?

(If don't see issue)

- From what you said I've understood that you feel comfortable with your ability to access land. Do you feel that your situation is unique? Are most women in a similar situation as you in terms of their ability to access land?

- So you have discussed the issue of.......... and the issue of....... How do you see these relating?

o What sort of steps could be taken to address these issues?

\section{Hypothetical Situation:}

If you were able to create the structure that determined how all the people (citizens) of Kanungu access land, both male and female, what would this look like? (Probe: Would you use the law? Would you use a different method? If law, what type pf laws would you create?

\section{Express Cultural Ignorance}

Well I have learned a lot, thanks. I had no idea about........thanks this was very informative.

\section{Friendly Questions:}

Can I know a little bit more about your family?

What is your favorite part of this area? As a foreigner what do you think I need to see or do or eat? 